\title{
The Evaluation of the Effect of the Marketing Mix Elements on the Performance of Pakat Restaurants Group
}

\author{
Dr. Mohammad Haghighi \\ Associate Professor, Faculty of Management, University of Tehran, Tehran, Iran \\ Dr. Tahmoures Hasangholipour Yasvari \\ Associate Professor, Faculty of Management, University of Tehran, Tehran, Iran \\ Arghavan Taherkhanchi \\ MSc in MBA, Faculty of Management, University of Tehran, Tehran, Iran \\ Corresponding Author: Ta_arghavan@yahoo.com
}

Doi: $\quad$ 10.5296/ijld.v3i5.4529 URL: http://dx.doi.org/10.5296/ijld.v3i5.4529

\begin{abstract}
The present research was conducted with the purpose of examining the effect of the marketing mix elements on the performance of Pakat Restaurants Complex based on the surveys of the consumers and experts. The data were obtained from 171 questionnaires gathered from the consumers and the experts of the restaurant. Generally, all variables (including quality, price, information, packing, distribution and branding) were important according to the consumers and experts of this industry. The results showed that all variables were significant according to the consumers of this complex except the distribution. According to ANOVA table, the effect of all demographic variables on the level of quality showed a significant difference among the communities. The effect of the experience of the consumption on the price became also significant. According to the strategies predicted in Pakat Complex, it became clear that the performance of the complex was successful to derive customer's satisfaction and increase the number of loyal customers and is proved to promote a brand of healthy and high quality food for the consumers.
\end{abstract}

Keywords: Advertising, Marketing Mix Elements, Branding

\section{Introduction}

Entrance to the industrial society of the market whose formation gradually began after the industrial revolution in western countries and is more noticeable in the industrial developed countries has changed many things extensively. The evolved form of the industrial society of the market is the consumer society. This society makes it possible for the buyers to choose their desirable products.

For this reason, advertising and marketing linked together and the mutual need for the advertising industry, production and business is now necessary in the countries. In other words, advertising activities are followed to facilitate and increase the sale. These activities are indeed a kind of investment by the employers and firms in the hope of getting the cost back. Effective advertising is a tool to get reputation and helps the managers achieve their objectives more rapidly and create a communicational bridge between them and the customers. 
Advertising is in fact a subset of the activity of the sales promotion that is one of the marketing mix elements together with the product, price and location, and is one of the most important tools of informing the customers of the existence of a product as a promotional method and affects on the customer's mind to choose a product. Some believe that advertising is an event resulted from the free economy or is a harmful phenomenon that consumers have to tolerate due to the freedom of expression. But the fact is totally different. Advertising is a very important living force, because 1) it is a main tool in the competition between companies, 2) it is the first tool by which the firms introduce their new products to the consumers, 3) it is a big protector of the media in other countries, 4) it is a big industry [14].

The purpose of any advertisement is to change the level of the awareness, the impression and the preferences of the consumer or the audience and the advertising strategy states the way to achieve this purpose. This strategy is generated based on accurate research on the audiences, especially the target audiences, the advantages and the values of the product or the subject, the appropriateness of the media and the features of the advertising message. Advertising strategy makes the advertising follow its route correctly.

\section{Problem description}

Human is a creature that needs to confront the environment to live and survive and has fought against the limitations differently to meet his needs. Paying attention to the customers' needs and identifying their behavior and the way of selling the products and extending the available markets have added a modern science to the human knowledge called "marketing". In contrast to the view of some people, marketing is not only short term and discontinuous attempts to sell the remaining products that are not still sold. Marketing is a human and social activity that continues from the stage of identifying the consumers' need to the time of distributing the product to the end user. For this purpose, the science of marketing plays an important and proper role. Marketing is the activities of the human force directed towards supplying the needs and demands by exchanging the processes. The purpose of the producers is to increase the sale and consequently to achieve more profit that makes them able to control some parts of the market and protect their market share. The purpose of the consumer or the buyer is to be satisfied with his transaction. Therefore, there is a two-way relation between these two important groups of the producer and consumer and this relation is worth being examined and thought.

Therefore, marketing researchers must distinguish the consumer's behavior from his reaction to the factors effective in the buying process to meet and plan his needs.

As one of the most important tools of the marketing mix, advertising can play an important role in the marketing policies and strategies of a company such as communicating with customers, and modifying and changing their opinions about the company [4].

It can be said that the food industry accounts for a high part of the family's income in Iran and at present, it is the only industry in which a complete competition exists. It seems that advertising can play a very effective role in this industry. We face the broadcast of different commercial announcements and different ways of introducing products in the television, radio, newspapers and general and professional magazines every day.

\section{The importance of the research}

According to the development of the technology and the mass production of the products, planning for the success in the market is one of the most sensitive and important issues of the business. The competitive conditions of the market have made this issue more important. Therefore, it is very important to pay attention to the advertisement as one of the marketing elements. Today, the correlation of advertising and marketing with the knowledge such as literature, music, graphics, photography and painting shows that many factors are effective in 
the success of the advertisement of the products. Marketing managers must answer the questions that "which product is produced at which price and in which place and by which advertising methods". It is evident that these controllable factors of the marketing management are determined according to the environmental conditions (political, economical, commercial, cultural, etc) that are effective in the activities of the firm. As a result, marketing managers must provide and offer the products or services of the consumers according to their needs and the resources of the organization.

Since the main field of the activity of the marketers is the mind of the consumers, marketing managers must change the common belief about a product and direct it towards their purpose to finally increase the sale. Other factors that account for the necessity of the advertisement are as follows:

1. Due to the increase of the companies producing similar products and the competitiveness of the market, customers don't buy a product easily and they must be convinced.

2. Advertising informs the customers of the latest developments.

3. Suitable and viable advertising is a kind of intangible support for a company and its products that finally makes the company's products be accepted extensively. Finally, according to what was mentioned, suitable advertising is needed to help the company remain dynamic in the competitive environment.

\section{Purposes of the research}

The major purpose of the research is to evaluate the effect of the marketing mix elements on the performance of Pakat Restaurants Group. The following minor purposes must be achieved to achieve the major purpose.

- Measuring the success of Pakat Institute in terms of paying attention to the product's quality

- Evaluating the performance of Pakat Complex in the pricing process

- Evaluating the attitude of Pakat Complex towards methods of distribution and marketing

- Examining the information methods in Pakat Complex

- Measuring the performance of Pakat Complex in packing the products

- The importance of the brand or the trademark in the success of Pakat Complex

\section{Hypotheses of the research}

\section{The major hypothesis}

Marketing mix elements affect on the evaluation of the consumers of Pakat Complex

\section{The minor hypotheses}

- The quality of Pakat's products is important according to the customers.

- The price of Pakat's products is important according to the customers.

- The way Pakat's products are distributed and marketed is important according to the customers.

- Information of Pakat Complex is important according to the customers.

- The way Pakat's products are packed is important according to the customers.

- The brand of Pakat Complex is important according to the customers.

\section{History of the research}

In this section, the history of the research is briefly presented inside and outside of Iran as the following table: 
Table 1. The history of the research

\begin{tabular}{|c|c|}
\hline $\begin{array}{l}\text { Researcher's } \\
\text { name }\end{array}$ & Subject of the research \\
\hline $\begin{array}{l}\text { Mina } \\
\text { Maghsoudzadeh } \\
(2010)\end{array}$ & $\begin{array}{l}\text { The effects of the advertising programs of Ramak diaries on the trademark, } \\
\text { Tehran University }\end{array}$ \\
\hline $\begin{array}{l}\text { Mostafa } \\
\text { Behashti } \\
\text { Seresht (2007) }\end{array}$ & $\begin{array}{l}\text { The evaluation of different approaches to formulate the strategy of the } \\
\text { development of new products Sharif University of technology }\end{array}$ \\
\hline $\begin{array}{l}\text { Shirin Aslani } \\
(2009)\end{array}$ & $\begin{array}{l}\text { The dynamic pricing model of the limited-life products together with } \\
\text { considering the advertisement, sharif University of technology }\end{array}$ \\
\hline $\begin{array}{lr}\text { Bahareh } & \text { Neko } \\
\text { Asl } & \text { Azadeh } \\
(2010) & \\
\end{array}$ & $\begin{array}{l}\text { The effect of the commercial advertisements on the behavior of the } \\
\text { consumers of the sanitary-cosmetics products, Tehran University }\end{array}$ \\
\hline $\begin{array}{l}\text { Abdolvahed } \\
\text { Mehdi } \\
\text { Alamdarlou } \\
\text { (1998) }\end{array}$ & $\begin{array}{l}\text { The effect of the commercial advertisements on the consumers' behavior in } \\
\text { the food industries of Iran (Yek-o-Yek Inc.), Tehran University }\end{array}$ \\
\hline $\begin{array}{l}\text { Fereshteh } \\
\text { Mansouri } \\
\text { Moayad (2004) }\end{array}$ & $\begin{array}{l}\text { The effectiveness of the commercial announcements of the banking services } \\
\text { of Maskan Bank, Alameh Tabataei University }\end{array}$ \\
\hline $\begin{array}{l}\text { Sandra Kanrez } \\
(2002)\end{array}$ & $\begin{array}{l}\text { The effects of the environmental involvements and criteria on the } \\
\text { effectiveness of the advertisement, Mississippi University }\end{array}$ \\
\hline $\begin{array}{l}\text { Clark et al. } \\
(2009)\end{array}$ & The effect of advertising on brand awareness and quality perception \\
\hline $\begin{array}{l}\text { Macdonald\& } \\
\text { Sharp (2003) }\end{array}$ & $\begin{array}{l}\text { In this research, the management perception of the importance of brand } \\
\text { awareness as an advertising effectiveness is examined. }\end{array}$ \\
\hline $\begin{array}{l}\text { Ayanwale, } \\
\text { Alimi, } \\
\text { Ayanbimipe } \\
(2005)\end{array}$ & The influence of advertising on the brand preference of the consumer \\
\hline
\end{tabular}

\section{Methodology of the research}

This article is the result of a study with an applied purpose and an analytical-descriptive method. The population of the research includes the consumers of Pakat Complex. The suitable sample of the present research is 171 consumers based on sampling the unlimited communities of the consumers and 15 experts. Internal consistency measurement of the questionnaire was used by measuring Cronbach's alpha coefficient to determine the reliability of the questions of the questionnaire; this coefficient was obtained higher than 0.7 for the questions of all variables of the research. Therefore, findings show the reliability of the instrument. The results of Kolmogorov-Smirnov test show that the collected data are normal. Now we compare the mean of the research's variables with the mean value 3. Since the mean value of a population is compared with one, one- sample t-test is used. In all tests, if the level of significance (Sig.) is more than the error $(0.05), H_{0}$ is supported and if it is less than the error $(0.05), H_{1}$ is supported.

The first question: the level of the importance of the mentioned factors according to the customers 
Table 2. The results of the one-sample t-test of the importance of the mentioned factors according to the customers

\begin{tabular}{|l|l|l|l|l|}
\hline \multicolumn{1}{|c|}{ Measure } & \multicolumn{1}{|c|}{ Mean } & \multicolumn{1}{c|}{ T statistic } & \multicolumn{1}{c|}{$\begin{array}{c}\text { Degree of } \\
\text { freedom }\end{array}$} & Sig. \\
\hline $\begin{array}{l}\text { Product } \\
\text { (quality) }\end{array}$ & 4.0202 & 30.400 & 155 & 0.000 \\
\hline Price & 3.9808 & 13.227 & 155 & 0.000 \\
\hline Distribution & 3.9551 & 15.872 & 155 & 0.000 \\
\hline Information & 3.7917 & 12.665 & 155 & 0.000 \\
\hline Packing & 3.8889 & 26.017 & 155 & 0.000 \\
\hline
\end{tabular}

According to the results obtained from the one-sample t-test, the level of the importance of all mentioned factors is desirable according to the customers (they are very important).

The second question: the level of the customers' satisfaction of the mentioned factors in Pakat Restaurants

Table 3. The results of the one-sample t-test of the customers' satisfaction of the mentioned factors

\begin{tabular}{|l|l|l|l|l|}
\hline \multicolumn{1}{|c|}{ Measure } & \multicolumn{1}{|c|}{ Mean } & \multicolumn{1}{c|}{ T statistic } & \multicolumn{1}{c|}{$\begin{array}{c}\text { Degree of } \\
\text { freedom }\end{array}$} & Sig. \\
\hline $\begin{array}{l}\text { Product } \\
\text { (quality) }\end{array}$ & 3.4433 & 12.156 & 155 & 0.000 \\
\hline Price & 3.7372 & 8.735 & 155 & 0.000 \\
\hline Distribution & 2.8910 & -1.662 & 155 & 0.098 \\
\hline Information & 3.1442 & 2.047 & 155 & 0.042 \\
\hline Branding & 3.8370 & 22.657 & 155 & 0.000 \\
\hline Packing & 3.6261 & 10.296 & 155 & 0.000 \\
\hline
\end{tabular}

According to the results obtained from the one-sample t-test, the level of the customers' satisfaction of all mentioned factors (except the distribution) is desirable (customers are satisfied with all factors except the distribution).

The third question: the level of the importance of the mentioned factors according to the experts

Table 4. The results of the one-sample t-test of the importance of the mentioned factors according to the experts

\begin{tabular}{|l|l|l|l|l|}
\hline \multicolumn{1}{|c|}{ Measure } & \multicolumn{1}{|c|}{ Mean } & \multicolumn{1}{c|}{ T statistic } & \multicolumn{1}{c|}{$\begin{array}{c}\text { Degree of } \\
\text { freedom }\end{array}$} & \multicolumn{1}{c|}{ Sig. } \\
\hline $\begin{array}{l}\text { Product } \\
\text { (quality) }\end{array}$ & 4.3487 & 14.775 & 14 & 0.000 \\
\hline Price & 4.1333 & 6.859 & 14 & 0.000 \\
\hline Distribution & 4.3500 & 10.689 & 14 & 0.000 \\
\hline Information & 3.9000 & 4.583 & 14 & 0.000 \\
\hline Packing & 4.3556 & 12.880 & 14 & 0.000 \\
\hline
\end{tabular}

According to the results obtained from the one-sample t-test, the level of the importance of all mentioned factors is desirable according to the experts (they are very important).

The fourth question: the level of the experts' satisfaction of the mentioned factors in Pakat Restaurants 
Table 5. The results of the one-sample t-test of the expertss' satisfaction of the mentioned factors

\begin{tabular}{|l|l|l|l|l|}
\hline \multicolumn{1}{|c|}{ Measure } & \multicolumn{1}{|c|}{ Mean } & \multicolumn{1}{c|}{ T statistic } & \multicolumn{1}{c|}{$\begin{array}{c}\text { Degree of } \\
\text { freedom }\end{array}$} & Sig. \\
\hline $\begin{array}{l}\text { Product } \\
\text { (quality) }\end{array}$ & 4.0974 & 8.729 & 14 & 0.000 \\
\hline Price & 3.9333 & 4.090 & 14 & 0.001 \\
\hline Distribution & 4.0500 & 4.996 & 14 & 0.000 \\
\hline Information & 3.9333 & 4.090 & 14 & 0.001 \\
\hline Branding & 3.9905 & 6.951 & 14 & 0.000 \\
\hline Packing & 4.3556 & 16.387 & 14 & 0.000 \\
\hline
\end{tabular}

According to the results obtained from the one-sample t-test, the level of the experts' satisfaction of all mentioned factors is desirable (experts are satisfied with all factors).

\section{Discussion and conclusions}

Advertising is an element of the process of the economic growth and development and is directly related to the economic prosperity and is a driving force and a necessity for the developing countries such as Iran that move towards the professional trade. For this reason, using modern knowledge and technology can draw the success route of a company and a manger. Effective advertising is a tool to get reputation and helps the managers achieve their objectives more rapidly and create a communicational bridge between them and the customers. The emergence of reputation begins from small points and gradually expands like an avalanche.

What can be mentioned as the result of the discussion is that the involved elements must correctly interact with the advertising system in order that it is successful. If we consider advertisement as the main gear, other gears (advertising companies, producers, audience, media, government and the public) must be put at their right position and move correctly. Otherwise, the movement of the system is disturbed. This movement needs comprehensive planning. It is necessary in planning that all of the problems are first proposed and noticed, and the barriers are examined. In the period of a product's growth and maturity in its lifecycle when there is a demand for the product and the product must be given prominence, the main task of the advertisement is to explain and prove the privileges of the company's product to the similar products. In this stage, since there is a competition for the product, a convincing advertisement can create a special differentiation for the product and make the consumer aware to choose and buy the products.

The results of the research showed that the importance of all marketing mix elements is significant according to the customers. In addition, the customers' satisfaction of all marketing mix elements became also significant in Pakat Complex except the distribution, and it is due to the delay (from getting orders to provide the product) of this complex in the distribution and it has not been successful to derive customer's satisfaction, and this may be due to the inexperience of the staff of this complex.

The results of the research showed that quality is significantly related to the variables including age, sex, employment, education, experience of using the products and the region of the residence.

The results of examining the effect of the employment and the experience of using the product on the quality showed that according to the bureaucratic structure of the region including public and private companies, the number of the responding employees is higher than other employments. Most customers had used the products of this complex 2-5 times and they can be considered as the loyal customers. According to the strategies predicted in Pakat Complex, it 
became clear that advertising was successful to derive customer's satisfaction and increase the number of loyal customers and is proved to promote this complex as a healthy food and high quality brand for the consumers.

In this research, the high frequency percentage of the females showed the importance that this class of the society attach to healthy foods. As it seems, advertisement in the food industries is based on the fact that focusing on the women of the families to derive their satisfaction can be a key and successful factor of the success.

Among other variables, 31-40 years old people, those with bachelor's degree and those living in other regions were most of the consumers of the complex.

The results also showed that price is not significantly related to the variables including sex, employment, education, and the region of the residence, but it is significantly related to age and the experience of using the products. The pricing method is Van Vastandrope method in this complex that determines the customers' sensitivity to price. This method includes very high, high, low and very low prices. When the price is very high, the product is not bought and when the price is very low, its quality is suspected and it is not bought again. It shows the success of the complex in its pricing strategy that was also mentioned in its advertising and it found new markets to present the products by giving discounts and established advertising campaigns to offer buying facilities to the loyal customers. People's age and experience of using the products affect on the price. It means that price is an effective factor for the employed 31-40 years old people.

According to the nature of the product being studied ((healthy easy consumption foods), it can be said that this subject is rarely studied and therefore, there is an innovation in this research.

\section{Suggestions}

Finally, the management of this complex is suggested to pay attention to the following points:

- Distribution must be noted in this complex, because according to some consumers, the complex has performed weakly in this case. Of course, since this complex is newly founded and its staff is not very experienced, this lack is expected.

- According to the evaluation of all factors by the consumers and their high satisfaction of the complex, the complex must communicate constantly with the customers, apply innovation and diversity to its products and use strategic programs while considering in which stage of its lifecycle the product is.

- According to the high competition of this industry, the survival of the brand, the brand's share and the creation of new markets must be noted.

- It is suggested that new branches are located in the residential areas of Tehran, because there are always customers in these areas and the sale will increase.

\section{References}

1. Aslani, Sh. (2009), The dynamic pricing model of the limited-life products together with considering the advertisement, Sharif University of technology.

2. Neko Asl Azadeh, B. (2010), The effect of the commercial advertisements on the behavior of the consumers of the sanitary-cosmetics products, Tehran University.

3. Behashti Seresht, M. (2007), The evaluation of different approaches to formulate the strategy of the development of new products, Sharif University of technology.

4. Rousta, A., Venous, D.,\& Ebrahimi, A. (2008), Samt Pub., Tehran.

5. Sanian Rad, M. (1990), communications, Soroush pub., Tehran.

6. Sanayeei, A. (1995), principles of marketing and market management, Porsesh Pub., Isfahan. 
7. Alamdarlou, A. (1998), The effect of the commercial advertisements on the consumers' behavior in the food industries of Iran (Yek-o-Yek Inc.), Tehran University.

8. Kanrez, S. (2002), The effects of the environmental involvements and criteria on the effectiveness of the advertisement, Mississippi University.

9. Maghsoudzadeh, M. (2010), The effects of the advertising programs of Ramak diaries on the trademark, Tehran University.

10. Mansouri Moayad, F. (2004), The effectiveness of the commercial announcements of the banking services of Maskan Bank, Alameh Tabataei University.

11. Ayanwale, A., Alimi, T. \& Ayanbimipe, M.A. (2005), The influence of advertising on the brand preference of the consumer, Department of Agricultural Economics, Obafemi Awowle University, lie-ife. Osun State, Nigeria.

12. Clark, C., Daraszelski, U.\& Draganska, M. (2009), The effect of advertising on brand awareness and quality perception, Quantitative Marketing and Economics, vol. 7, issue 2, pp. 207-236.

13. Macdonald, E. \& Sharp, B. (2003), Management perception of the importance of brand awareness as an advertising effectiveness, Marketing Bulletin 14, Article 2.

14. Tellis, Gerard J. (2004), Effective advertising, Sage Pub. 